Portland State University

PDXScholar

$1-1-2011$

\title{
Threshold Concepts and Information Literacy
}

Lori Townsend

University of New Mexico

Korey Brunetti

California State University

Amy R. Hofer

Portland State University, hofera@linnbenton.edu

Follow this and additional works at: https://pdxscholar.library.pdx.edu/ulib_fac

Part of the Library and Information Science Commons

Let us know how access to this document benefits you.

\section{Citation Details}

Townsend, L., Brunetti, K., \& Hofer, A. R. (2011). Threshold Concepts and Information Literacy. Portal: Libraries And The Academy, 11(3), 853-869.

This Article is brought to you for free and open access. It has been accepted for inclusion in Library Faculty Publications and Presentations by an authorized administrator of PDXScholar. Please contact us if we can make this document more accessible: pdxscholar@pdx.edu. 
Lori Townsend

Data Librarian for Social Sciences and Humanities

University of New Mexico Libraries

Korey Brunetti

Reference and Instruction Librarian

California State University, East Bay, University Libraries

Amy R. Hofer

Distance Learning Librarian

Portland State University Library

Threshold Concepts and Information Literacy

Abstract

What do we teach when we teach information literacy in higher education? This paper describes a pedagogical approach to information literacy that helps instructors focus content around transformative learning thresholds. The threshold concept framework holds promise for librarians because it grounds the instructor in the big ideas and underlying concepts that make information literacy exciting and worth learning about. This paper looks at how this new idea relates to existing standards and posits several threshold concepts for information literacy.

Introduction 
What do we teach when we teach information literacy in higher education? There is certainly no shortage of published guidelines, standards, teaching strategies, and advice awaiting the motivated instruction librarian. The literature abounds with the profession's collective efforts to improve teaching by searching out meaningful instructional content.

Yet while information literacy program statements and policies generally espouse goals of critical thinking and lifelong learning, research on the practice of information literacy instruction finds that it is often taught as a kind of enhanced bibliographic instruction. This dissonance between espoused theories and theories-in-use suggests that while many innovative approaches have been theorized, librarians in the trenches sometimes struggle to relate theory to practice. ${ }^{1} \mathrm{We}$, the authors, began our exploration of improving information literacy instruction because we felt that our own teaching was not as effective as it could be.

This paper aims to advance the conversation around this issue by introducing threshold concepts, a pedagogical strategy designed to help instructors in higher education identify and teach foundational disciplinary concepts. It provides an overview of threshold concepts, looks at how they are already being applied to the field of information literacy instruction, and addresses related questions of disciplinarity and existing standards. It then describes the process of identifying threshold concepts and how this model was applied to a two-credit information literacy course, required for first-year students.

Improving student learning is always on the minds of instruction librarians, especially given the current emphasis on measurable outcomes in the world of higher education. This paper does not look quantitatively at whether this approach has an impact on student learning, but rather asserts that this approach offers a way to focus and prioritize instructional content and 
leads to engaged teaching. As such, it is a model that we hope instruction librarians will consider, especially when designing curricula.

Learning about threshold concepts encourages contemplation based on classroom experience and disciplinary knowledge. This sparks a process of questioning, brainstorming, and theorizing about how to share the big ideas that make information science exciting and worth learning about.

Threshold Concepts: An Overview

Introduced by Jan Meyer and Ray Land, threshold concepts are the eore ideas and processes that define the ways of thinking and practicing for a discipline, but are so ingrained that they often go unspoken or unrecognized by practitioners. "Ways of thinking and practicing" is a phrase coined by the Enhancing Teaching-Learning Environments in Undergraduate Courses research project, where Meyer and Land's work on threshold concepts originated; it refers to these central concepts that transform and integrate students' view of content and bring insight into how to think like practitioners themselves. In their pioneering article, Meyer and Land propose the following criteria for threshold concepts:

- transformative-causes the learner to experience a shift in perspective; is

- Sintegrative-brings together separate concepts (often identified as learning objectives or competencies) into a unified whole;

- irreversible-once grasped, cannot be un-grasped;

- troublesome-often counter-intuitive, the place where students stumble or get stuck; 
- bounded-may help define the boundaries of a particular discipline, are perhaps unique to the discipline. ${ }^{3}$

Because threshold concepts hold the potential to transform the way students think about both the subject matter of disciplines and how disciplinary structures map to different areas of knowledge, Meyer and Land draw a distinction between this type of perspective shift and the traditional learning objective, which must be mastered for the student to progress but "does not necessarily lead to a qualitatively different view of subject matter."4 Threshold concepts are like learning objectives in that they can provide a focus for curriculum design and may prove to be a tool with which to measure student learning. However, threshold concepts differ from learning objectives in that they are gateways for student understanding that, once traversed, transform the student's perspective. As Peter Davies explains, "When an individual acquires a threshold concept the ideas and procedures of a subject make sense to them when before they seemed alien. It is the threshold concept that provides the coherence."5

Meyer and Land suggest that teaching and learning across the disciplines may be improved by employing the threshold concept framework. Because threshold concepts are built around the material that often stumps students, disciplinary experts are well-positioned to identify the "stuckplaces" and their related learning thresholds. ${ }^{6}$ Their Times Higher Education Supplement article written for teaching faculty emphasizes how the threshold concept model of course design may prove empowering for instructors. Because it relies on disciplinary expertise rather than "managerial" theoretical templates, academics "are not required to bring with them the baggage of a separate education jargon."7 This may come as welcome news to librarians who, like many academics, take on teaching responsibilities without formal pedagogical training. 
Because Meyer and Land's work examines threshold concepts across a number of different disciplines, reading this literature provides the opportunity to identify common instructional difficulties and consider how they are handled. For example, Ursula Lucas and Rosina Mladenovic observe that students in mandatory accounting courses that employed threshold concepts were better able to see the "why" of this discipline, and "see well beyond their initial preconceptions and take on a new world view." 8 This is especially resonant for information literacy instructors who, like accounting professors, frequently teach students who see no clear need for information literacy instruction and are not likely to progress beyond these preconceptions if the focus is solely on the tools and procedures of information use.

The threshold concept literature also engages with the important question of whether teaching with threshold concepts might exacerbate troubling power relations within the classroom. ${ }^{9}$ Does using threshold concepts to draw students into the ways of thinking and practicing in a discipline privilege those ways of thinking and practicing, thereby reproducing power imbalances that often go unaddressed in academia? Would this mean asking students to see through a particular disciplinary lens which might itself be the historical product of, or implicitly validate, entrenched ideologies? And do these complex dynamics contribute to student anxiety? In response to these issues, cultural studies scholar Glynis Cousin asserts that if higher education does not raise fundamental questions in students, there is "a problem of domestication wherein the radical, transformative capacity of a concept is tamed by traditional academic assessment requirements. ${ }^{, 10}$ In this view, encouraging students to change how they see the world - and possibly themselves - is not something to be avoided. It is essential to the process of teaching and learning. 
There is, of course, a considerable body of work on pedagogy for instruction librarians, from books, articles, and reports to dedicated conferences and lively online discussions. Threshold concepts may be perceived as a retread of previous ideas, per Cousin's piece titled "Threshold Concepts: Old Wine in New Bottles or a New Form of Transactional Curriculum Inquiry?" knowledge and skill acquisition (for example, Gestalt learning theory, phenomenography, constructivism, and cognitive psychology). ${ }^{12}$ What makes the threshold coneept approach unique is its focus on transformative, disciplinary content, which can be a highly productive way to think through teaching material and reconnect with the students' experience of it.

Threshold concepts have the potential to help address the "why" questions that students often pose: Why do I need to learn about this database? What's the point of citing this paper correctly? When will I ever need to know about peer review? Why is this course required? Threshold concepts can answer these questions in more meaningful ways by grounding procedural instruction in a disciplinary context.

Threshold Concepts as Used by Other Information Literacy Practitioners The literature includes three examples of librarians using the threshold concept framework for information literacy instruction. Denyse Rodrigues and DeNel Rehberg Sedo used threshold concepts to inform their ethnographic study of students learning to use and evaluate communication tools in Second Life. ${ }^{13}$ Phil Yorke-Barber, Loretta Atkinson, Gisela Possin, and Leith Woodall conducted a comparative survey of academics and students to identify learning thresholds in the research process for engineering students. ${ }^{14}$ Margaret Blackmore's work 
documents a series of workshops designed to collaboratively identify threshold concepts within the context of information literacy. ${ }^{15}$

The first two studies understand information literacy, as a whole, as a single threshold concept. Rodrigues and Sedo state that "Using a constructivist definition of information literacy presents it as a threshold concept because we see information literacy as a social practice that extends beyond information gathering skills." 16 Similarly, in Yorke-Barber et al, "information research is not a discipline and does not have discipline-specific threshold concepts... Information research is itself a threshold concept." ${ }^{\prime 17}$

Blackmore, on the other hand, posits that there are specific threshold concepts associated with information literacy. ${ }^{18}$ By way of analogy, "economics" is not a threshold concept, but "opportunity cost" is a threshold concept within the discipline of economics. ${ }^{19}$ Blackmore's workshops with help desk staff looked at studentstumbling blocks and attempted to identify the underlying threshold concepts. She points out that the process of defining threshold concepts leads us to "reconceptualise many of the ways that [we] perceive the information engagement process. Whilst not necessarily the goal, this is a valuable byproduct of the process of identifying threshold concepts."20

All three papers propose thresholds that are not necessarily focused on the content of information literacy. As mentioned above, for Rodrigues and Sedo, and Yorke-Barber et al, information literacy itself is a threshold concept, which seems to preclude the existence of distinct threshold concepts within the domain of information literacy. ${ }^{21}$ While Blackmore's work identifies some excellent candidates for information literacy related thresholds, it also includes threshold concepts related to time management, academic acculturation, and emotion. ${ }^{22}$ Librarians regularly encounter students struggling to adjust to the academic environment, but 
these problems are not unique to the reference desk. Biologists or historians would be unlikely to point to issues with time management or student affect as core concepts in their respective disciplines. Similarly, it can be argued that there are distinct threshold concepts for information literacy and that they relate to the discipline of information science.

Naomi Irvine and Patrick Carmichael point out that identifying threshold concepts can help to "exemplify discipline-specific conceptual frameworks.",23 In working to identify threshold concepts in a discipline, it is useful to ask whether the concepts are truly unique to the content of that discipline. Defining threshold concepts for information literacy, then, is an opportunity for a discussion about disciplinary identity.

Threshold Concepts in Context

Information literacy was first officially defined in 1989 by the American Library Association (ALA) as "the ability to recognize when information is needed and to locate, evaluate, and use effectively the needed information."24 Over the years, a tremendous variety of theoretical models and approaches to information literacy have proliferated and hundreds of scholarly articles about the topic are published every year. ${ }^{25}$ Some approaches offer concrete and practical research process models and standards for content. Others theorize how information literacy is perceived and the cognitive, social, or relational processes that underlie the locating, evaluating, and using of information. Yet another branch focuses on effective teaching techniques, regardless of content. Paulette Kerr provides a useful summary that highlights the breadth of conceptualizations of information literacy:

Definitions of [information literacy] range from being equipped with discrete generic skills, constructing knowledge, critical thinking, enabling life long learning, a process of 
knowing, a process of acquiring new meaning and understanding, enabling the effective utilization of information for a purpose, and a complex of ways of experiencing information use. $^{26}$

For the librarian who wants to progress beyond teaching students how to use the library and address some of the more complex themes of information literacy, the question of what to teach and how to teach it can seem very complicated.

Threshold concepts allow the practitioner to use classroom observation and disciplinary knowledge to make decisions about meaningful and transformative instructional content, without necessarily being fluent in the wide-ranging discourse of information literacy. They do not require the practitioner to subscribe to a particular theory of information literacy or pedagogical technique. It is likely that threshold concepts would work in a complementary fashion with many approaches, especially those that seek a deeper meaning and more nuanced understanding of information literacy. The interplay between the various theoretical approaches to information literacy and threshold concepts certainly merits further research. It is the acknowledgement of more complex and interesting content beneath the surface of information literacy's lists of tasks and processes, and a simpler way to uncover and explain that complexity, that makes threshold concepts so exciting.

Employing the threshold concepts approach to information literacy has implications beyond the very practical one of identifying content around which to design curricula: it suggests that information literacy has unique content outside of the context of other disciplines. This view challenges the widely accepted idea that information literacy is best approached by embedding its content within the processes of other disciplines. Rather than taking a position in the ongoing debate about information literacy as a discipline, ${ }^{27}$ for the purpose of using the threshold concept 
approach it is useful to situate information literacy in the context of the discipline most concerned with information production, organization, and use - information science. While "information literacy" may not be a discipline per se, the common way of thinking and practicing shared by information professionals constitutes a body of knowledge for which there are learning thresholds.

Thinking about information literacy as distinct from other disciplinary content is, perhaps, especially counterintuitive for librarians schooled in the belief that we are not concerned with making little librarians out of our students. Yet other disciplinary classes that students will take as part of their undergraduate education introduce the ways of thinking and practicing of the discipline. It is understood, for example, that very few of the students in Biology 101 are going to become biologists, but the students, the professor, the textbook author, and the administration understand that Biology 101 is an introduction to the ways of thinking and practicing used by biologists. Threshold concepts can help librarians apply that understanding to information literacy instruction. The work of information literacy instructors, therefore, is to expose students to the threshold concepts of librarians' discipline -information science - and help students to cross them.

The Trouble with Standards

Since threshold concepts place the focus on the content taught by librarians, what do they offer that differs from what is already available in terms of content guidelines? Librarians often look to standards, such as those published by the Association of College and Research Libraries (ACRL), the Society of College, National and University Libraries (SCONUL), and the Australian and New Zealand Institute for Information Literacy (ANZILL), for guidance on what 
to teach, both in our own classrooms and across the curriculum. However, existing standards do not provide adequate practical content guidance for teaching librarians.

Information literacy standards share some of the problems common to similar documents in any discipline. Grant Wiggins and Jay McTighe, originators of the backward design approach to curriculum development, identify three problems typically associated with content standards:

- the "overload problem" - too much content for too little time

- the "Goldilocks problem" - standards are either too big or tog small

- the "nebulous problem" - a standard is so vague as to be variously interpreted by different parties, thus reducing its effectiveness as a standard. ${ }^{28}$

Subjecting the ACRL Standards to a review based on the Wiggins and McTigue criteria, these problems emerge. First, there is the sheer scope of content to be covered: 5 standards, 22 performance indicators, and over 90 learning outcomes. ${ }^{29}$ Overload - certainly, even in the context of a quarter- or semester-long information literacy course, and even assuming that librarians use the standards selectively.

Second, the wide variation in the learning outcomes amply illustrates the Goldilocks principle:

Toosmall

is

\$Participates in electronic discussions following accepted practices (e.g.

"Netiquette")

Too big

Assesses the quantity, quality, and relevance of the search results to determine whether alternative information retrieval systems or investigative methods should be utilized 
Third, and finally, learning outcomes should be specific, measurable, and directly tied to the content at hand. However, many ACRL outcomes could be mistaken for the goals of the entire undergraduate curriculum:

\section{Too broad}

Integrates new information with previous information or knowledge

Draws conclusions based upon information gathered

Reflects on past successes, failures, and alternative strategies

Librarians certainly contribute to and support university-wide learning outcomes. But how are librarians uniquely qualified to teach the above? In trying to serve as both programmatic policy documents and provide straightforward classroom level curricular guidance, the ACRL Standards fail to do either adequately, as Owusu-Ansah asserts:

Perhaps the greater pitfall of the ACRL approach originated in its overwhelming desire to be all-inclusive and complete. Expedient or noble as that desire may appear, the thoroughness of what the drafters of the standards produced may well have compromised the practical viability of their work. ${ }^{30}$

It is understandable then, that novice instructors in search of guidance for teaching content may find the standards to be of limited use.

To addyet another dimension to the standards quandary, academic librarians face the common problem of explaining information literacy to departmental faculty. The determined non-librarian faculty members who read the entire ACRL standards document will likely have difficulty understanding and articulating what differentiates information literacy from critical thinking or other developmental milestones that form the backdrop of the undergraduate 
curriculum. They may then fall back on a definition of information literacy based on their own experiences as students: library user instruction.

Wiggins and McTighe suggest reframing standards to focus on the "big ideas" and/or "core tasks" of a discipline. ${ }^{31}$ These big ideas can be effectively identified by analyzing content through the threshold concept lens.

Identifying Threshold Concepts

We, the authors, first encountered threshold concepts at a workshop about moving courses into an online environment. This workshop introduced a cohort of disciplinary faculty to principles of curriculum design and basic educational theory including bąekward design, technology enhanced teaching, and threshold concepts. ${ }^{32}$ At the time, we were teaching LIBY 1210, a required twounit Introduction to Information Literacy course at California State University-East Bay. We had experimented with a hybrid approach organized using a class blog that incorporated a number of emerging technologies, such as wikis, alternative search engines, and cloud computing, alongside lessons on source evaluation and citation. This approach, while fresh, was ultimately only partially successful The students were more engaged, but did not demonstrate any greater competence or knowledge when compared to past students taught in a traditional classroom with conventionak âssignments and exercises. ${ }^{33}$

Employing the threshold concept approach led us to a closer examination of our course content and how we presented that content, in contrast to our previous attempt which used related technologies as an accompaniment to our traditional lessons. We examined our course objectives, which were based on the ACRL standards. We looked at other information literacy content online, in the form of tutorials and digital learning objects. We reflected on persistent 
student trouble spots - content areas where even diligent and attentive students, who attended class, listened to lectures, and completed all activities, often emerged confused or misinformed. We tried to identify unifying concepts that, once fully understood, would change our students' perspective and help them make sense of their information landscape.

The process of articulating possible candidates for unique information literacy thresholds was both iterative and discursive - we spent months hashing out our ideas, looking for weak spots, and talking through inconsistencies. We attempted to move back through the thresholds to uncover the tacit understandings we were taking for granted. As DavidPerkins observes, learners can "miss the target by miles, and teachers' more seasoned tacit presumptions can operate like conceptual submarines that learners never manage to detect or track." ${ }^{34}$ This re-imagining process slowly changed the way we understood information literacy instruction and forced us to make explicit things that seemed obvious to us. Some of our assignments, reexamined through this new lens, looked like busy work. In other cases, large gaps in our curriculum were revealed. ${ }^{35}$ The following sections propose several threshold concepts for information literacy.

\section{Proposed Information Literacy Threshold Concepts}

\section{Format as Process}

The format-retated threshold concept was inspired by a student's deceptively simple question: "What's the difference between a journal and a website?" It is understandable for a student to think that everything that appears in a browser window - book, newspaper, journal, blog, etc. is a website. Students run into trouble, however, when the language that they bring to school ("website" means "I found it online") bumps up against the more specific definition that librarians teach them. 
Instruction librarians often approach the question of format by listing the differences for students in tables that show the presence or absence of attributes such as peer-review, informal tone, and pictures. Librarians hope to familiarize students with the real-world object that the .pdf reproduces in order to give them the analog frame of reference for a digital object - even wheeling in carts piled with examples of bound periodicals, real books, and popular magazines. The problem with this approach is that it is based on a false dichotomy between print and online information that makes sense to those who recall photocopying journal articles, but confuses students who might never before have encountered an article in print. It also fails to account for how the scholarly and popular publication process is changing all around us.

Using the threshold concept model requires the identification of the tacit understandings that make the distinction between a journal and a website automatic. What needs to be articulated about the nature of the sources librarians encourage students to use, beyond simply identifying format characteristics?

A threshold concept relating to format, then, would focus on the student understanding that format is the result of a process. Information is packaged in different formats because of how it was created and shared. Shifting the focus from the end product to the pattern of events which define information production fundamentally changes the conversation.

In the context of Meyer and Land's criteria, the format threshold concept is:

- Transformative: Understanding information formats as the result of different processes invites students to view information in the context of how, when, and by whom it was created. Rather than training students to recognize source types, this emphasis on process encourages the student to ask the right questions when they find any information source. The discourse moves from "what" 
(characteristics, features) to "why" (disciplinary communication, channels of production).

- Integrative: Meyer and Land state that a threshold concept "exposes the previously hidden interrelatedness of something." ${ }^{, 36}$ Students understand instinctively that you would not look in the school newspaper for a definitive onepage biography of Lincoln any more than you would check out a book of postmodernist film criticism to find this week's movie listings. Capitalizing on this understanding, instructors can guide students toward connecting what they understand through their own experiences with the underlying principle of why information formats are distinct entities. The format approach also integrates learning objectives relative to citationand evaluation. Not only must students be able to identify formats in order to choose the correct citation template, but more significantly, an understanding of how formats are created highlights their differences, attributes, and likelihood of meeting an information need.

- Irreversible: A student who approaches her information landscape with an understanding of its process-oriented architecture is unlikely to revert to a more simplistic or fragmented perspective.

- STroublesome: Observation of students' information retrieval behavior demonstrates that concepts around information formats are troublesome, and fall specifically into a category that Perkins calls "tacit." This type of troublesome knowledge is characterized by a perceived understanding of how to do something but without a "clear, reflective conception of what we are doing." ${ }^{37}$ Many students can readily summon up search results and find something that relates to a given 
research topic, but cannot differentiate between a news article, a reference source, or a government website. They rely on past practice to locate information and often are unaware of how unskilled they are at identifying what they find.

- Bounded: This threshold draws a boundary between what librarians and disciplinary faculty teach about source types. Librarians, as both instructors and collectors, see how formats like books and journals are in flux, and also how they are used and valued across different fields of study. Disciplinary faculty are more likely to take a narrower approach to formats, exemplified by the research assignment that excludes websites from the list of aceeptable sources. Students are rarely introduced to the processes involved in creating a source, and are left mystified by the meaning of "scholarly" and "peer-reviewed," let alone how a nursing research article differs from history research article. The questions raised by formats are a conceptual no man's land in academia, one that librarians are poised to claim.

\section{Authority is Constructed and Contextual}

Teaching about authority can be an uncomfortable return to the days of librarians as gatekeepers of information. It is tricky to teach that some kinds of expertise are more worthy than others without privileging certain sources of knowledge. As information culture continues its meteoric pace of change, librarians' critical evaluation skills have become more important than trusted print reference sources. But librarians still understand the value of carefully built bibliography lists and reference tools. They also recognize that all sources are not created equal, that authoritative voices exist in specific categories of knowledge, and that context is key to 
determining when to listen to these voices. At the same time, authority is not infallible, and there are gaps and errors in the systems that bestow it.

An authority threshold concept makes explicit the idea that authority is both constructed and contextual, based on evaluative criteria specific to the situation. An understanding of this concept enables students to critically examine a source - be it a Wikipedia article or a peerreviewed conference proceeding - and ask the relevant questions about its origins, context, and suitability for the information need of the moment.

This concept might seem roughly equivalent to ACRL's third information literacy standard, which states that an information literate student can "evaluate information and its sources critically." ${ }^{, 38}$ While evaluation is key to identifying authority, the notion that authority is both constructed and contextual acknowledges that certain voices are elevated through established rules and systems, while recognizing that not all circumstances call for the same evaluative criteria. With this perspective, a student might identify Wikipedia as an authoritative source for an article on how local area networks are built when he is setting up his personal LAN network, but understand that it is probably not an acceptable source when writing a paper on the historical development of LANs for a computer science course.

William Badke, in arguing for information literacy's place within a philosophy of knowledge, states that "we contextualize the information process by recognizing why the writer writes, the processes by which the information was allowed to be published, and how the reader reads it. But a proper epistemology also looks at the qualifications, presuppositions, and biases of the writer." ${ }^{39}$ A standards-based approach does not address the nuances of the evaluative and epistemological concerns presented by the question of authority. These concerns can drive how librarians teach concepts such as the peer review process, information flow in academic 
disciplines, and the myth of objectivity. The authority learning threshold unites lessons on source evaluation with the bigger ideas of how individuals consume information, what it means to be an authority in any given discipline, and how certain discourses are privileged.

\section{Information as a Commodity}

With so much free information just a keystroke away, it is not surprising that students experience confusion when confronted with issues of information value and intellectual property. Librarians have likely encountered students who are shocked when they are asked to pay for that perfect article they find on Google Scholar, or puzzled by the need for an account to access a database. They also witness students struggling to cite materials, not only in the application of citation styles but also in determining what needs citing. The malleability and easy access of Web content can naturally lead a student to believe that all content is both free and there for the taking. Is it any surprise that students look at the practices of paying for and properly attributing sources with some confusion?

The application of the economic concept "commodity" - something that has monetary value and can be traded e to information has certainly been explored before. ${ }^{40}$ But framing teaching around this concept ties together learning objectives such as citation, copyright, fair use, proprietary databases vs. open access, intellectual property, and other related issues. The threshold of understanding information as commodity answers the "why" behind each of these lessons, validating the need for attribution, the existence of copyright laws, and the importance of the Fair Use doctrine.

\section{Primary Sources and Disciplinarity}


Another potential threshold concept concerns primary and secondary sources. Librarians spend a lot of time at the reference desk helping students find primary sources for assignments. Students are often handed a brief definition of primary and secondary sources and struggle to apply that definition to real world sources. Definitions such as the one offered by the Reference and User Services Association of ALA, that "primary sources are original records created at the time historical events occurred or well after events in the form of memoirs and oral histories, ${ }^{, 41}$ typically emphasize using primary sources in a historical context to examine the past. This can leave the psychology or biology student looking for primary sources documenting original research bewildered.

Because each discipline creates and uses primary and secondary sources differently, the disciplinary expert is liable to perceive a straightforward definition where none exists (e.g. "journal articles are secondary sources"). The student enrolled in several classes in different disciplines can easily misunderstand the nature of primary and secondary sources, and thus miss how they can help clarify the particular way a discipline investigates, analyzes, assesses, critiques, and explains the world. Unless students understand the fundamental nature of disciplinarity and the purpose underlying academic inquiry in a specific discipline, they will be unprepared to grasp the nature and purpose of primary and secondary sources.

Librarians are uniquely positioned to transmit this understanding because of the multidisciplinary nature of information science and its focus on the production, dissemination, and preservation of information and knowledge across all of the disciplines. Threshold concepts may provide a way to teach that primary and secondary sources are defined by their proximity to the creation of new information and that what is meant by "primary" and "secondary" changes depending on the disciplinary context. Rather than assume that the difference is obvious, and 
covering only the procedural information involved in finding primary and secondary sources, a threshold concept approach introduces students to the idea that the nature of primary and secondary sources is complicated, messy, and somewhat counterintuitive.

Is the core of this threshold concept tied specifically to primary/secondary sources and their involvement in the creation of new knowledge? Or is it fundamentally an issue of understanding disciplinarity as a way of organizing academic inquiry? Or perhaps some combination of these concepts? Identifying primary and secondary sources as an area of difficulty points to their potential to transform student understanding.

\section{L-E-T-S-G-O... to the Library! The Threshold Concept that Wasn't}

This concept was suggested by a comedy routine performed by a middle school teacher who created cheerleader-style routines for her students and decided to praise them for something that she said they should be doing anyway: using the library (the title of this section is the "cheer" that she made up). With her non-librarian perspective, she managed to perfectly sum up a common frustration among information literacy instructors: why is it such a struggle to make information literacy relevant to students? Was there another threshold concept at the root of this problem? Applying Meyer and Land's five definitional criteria, this potential threshold concept is:

- Transformative: The idea that the library is part of the research process, and that the research process itself is worth examination and reflection, goes without saying for librarians. This realization can completely change the students' perception of reference librarians; students may realize for the first time that they can choose to make use of this service. 
- Integrative: Students can apply this new knowledge to future situations (the next school assignment or personal information need).

- Irreversible: Once students have positive experiences with librarians, they will build this step into their concept of research and resources.

- Troublesome: Asking a librarian for help is troublesome on a practical level because it seems to make everything take longer, and on a deeper level because it requires admitting to uncertainty. Asking a reference question may even necessitate unlearning the norms of the user's home culture, certainly an anxious process.

- Bounded: Physically and metaphorically, thelibrary is a bounded space within academia that is expressly dedicated to research. It is seductive to try to use the threshold metaphor for coming to this space. But is this concept bounded by the field of inquiry for information science? In other words, does information science "own" this concept?

Even though "Let's go to the library!" seemed to meet some of the definitional criteria, it falls apart without being rooted in a specific disciplinary content area. Similar difficulties experienced by students, but that are not information literacy threshold concepts, include starting a paper early énough to do a good job, reading articles downloaded from library databases, and IT troubleshooting. These are important skills that librarians often teach students (and faculty), but that does not make them disciplinary content for information science.

Threshold Concepts in Practice 
After defining core learning thresholds through analyzing our own students' "stuck places," we set out to redesign our ten-week class around these ideas. We began by creating a presentation that introduces students to various information formats, emphasizing the processes that lead to the creation of each format. The lesson explains why understanding format is critical to constructing a citation, searching a database, and determining source appropriateness. In this way, format becomes an organizing principle for teaching these key learning objectives. A later lesson revisits the concept of formats as process, exploring how digital content has both changed and re-established information formats; a related exercise has students identify Web content through a formats lens, defending their responses and describing the process.

Besides creating new content that mapped explicitly to our thresholds, adhering to this structure also prompted us to jettison content that was no longer relevant. The threshold concept literature echoes this point: "A focus on threshold concepts enables teachers to make refined decisions about what is fundamental to a grasp of the subject they are teaching. It is a 'less is more' approach to curriculum design. ${ }^{42}$ In our earlier teaching experiences, we found it easy to slide into a "more is better" approach, a predictable outgrowth of the constantly changing information landscape. New e-collections, Web resources, and citation management tools are certainly interesting and relevant subject material, but may not help students understand the individual, underlying threshold concepts. Adherence to this framework pared down our course while sharpening the focus on remaining content.

Looking beyond direct instructional applications, threshold concepts may also help to define information literacy in a way that makes practical sense to disciplinary faculty and perhaps dispel the perception of some faculty that information literacy is simply bibliographic instruction under a new name. Economics professors, for example, will instantly recognize 
opportunity cost as a learning threshold, one that their students must grasp before moving on to more advanced content. They might then understand how students' grasping of information formats is integral to their understanding of how to identify scholarly sources. Through articulating our core content in a way that is clear to disciplinary faculty, librarians can strengthen their case that information literacy is important content that needs to be more fully integrated into the higher education curriculum.

\section{Future Research}

There is much to be done in the way of research on threshold concepts in information literacy. Prior work in various fields suggests possible directions. Margaret Kiley and Gina Wisker examined the applicability of threshold concepts in doctoral research education through interviewing a selection of experienced doctoral supervisors, then analyzed their findings to formulate threshold concepts. ${ }^{43}$ Blackmore conducted a series of workshops with help desk staff to both identify conceptual trouble spots and translate these into threshold concepts. ${ }^{44}$ Loosely following these models, we arein the process of analyzing qualitative data collected from experienced information fiteracy instructors about student "stuck places," with the goal of contextualizing the threshold concepts discussed in this paper and identifying new concepts.

Student perspectives will need to be incorporated in order to evaluate threshold concepts' impact on learning. For example, Chris Cope and Lorraine Staehr measured student comprehension of two proposed threshold concepts in information systems education. ${ }^{45}$ Other learning assessments might be designed to measure the effectiveness of this approach. Davies suggests yet another enticing research possibility, the comparison of how disciplinary experts and students (who have yet to cross the threshold) analyze the same problem. ${ }^{46}$ Examining 
learners' thought processes and outcomes would greatly advance our understanding of how threshold concepts might be applied.

Further research might explore where threshold concepts intersect with established models for information literacy instruction. Comparing these various approaches would situate the threshold concept model within accepted information literacy instruction practice and offer another option to librarians seeking guidance on developing instructional content. Analyzing the different ways in which competing theories drive practice could encourage more congruence between stated goals of information literacy programs and the de facto goals when librarians are in action.

\section{Conclusion}

Threshold concepts offer a promising theoreticalframework for identifying and teaching information literacy content, particularly for instructors who are overwhelmed by competing standards and guidelines in their efforts to design curriculum. Empirical observations of students' challenges can illuminate content that is difficult or confusing, and provide opportunities to reconsider teaching content. Practitioners who are immersed in the language, practices, and quirks of academic research are likely to have difficulty recalling the beginner's mindset, but librarians need only look to their students for an understanding of where the troublesome content lies.

Lori Townsend is Data Librarian for Social Sciences and Humanities at the University of New Mexico Libraries; Korey Brunetti is Reference and Instruction Librarian at California State 
University, East Bay, University Libraries; Amy R. Hofer is Distance Learning Librarian at Portland State University Library.

${ }^{1}$ Paulette A. Kerr, "Conceptions and Practice of Information Literacy in Academic Libraries: Espoused Theories and Theories-In-Use" (PhD diss., Rutgers, The State University of New Jersey, 2010), http://mss3.libraries.rutgers.edu/dlr/TMP/rutgers-lib_27317-PDF-1.pdf (accessed 8 April 2011).

${ }^{2}$ Jan H.F. Meyer and Ray Land, Threshold Concepts and Troublesome Knowledge: Linkages to Ways of Thinking and Practising Within the Disciplines, ETL Project Occasional Report 4 (Edinburgh: Enhancing Teaching-Learning Environments in Undergraduate Courses Project, 2003): 9, http://www.etl.tla.ed.ac.uk/docs/ETLreport4.pdf (accessed 8 April 2011).

${ }^{3}$ Ibid., 4-5.

${ }^{4}$ Jan H.F. Meyer and Ray Land, "Threshold Concepts and Troublesome Knowledge: An Introduction," in Overcoming Barriers to Student Understanding: Threshold Concepts and Troublesome Knowledge, ed. Jan H.F. Meyer and Ray Land (London: Routledge, 2006), 6.

${ }^{5}$ Peter Davies, “Threshold Concepts: How Can We Recognise Them?" in Overcoming Barriers to Student Understanding, ed. Meyer and Land, 74.

${ }^{6}$ Jan H.F. Meyer and Ray Land, “Threshold Concepts and Troublesome Knowledge (2):

Epistemological Considerations and a Conceptual Framework for Teaching and Learning," Higher Education: The International Journal of Higher Education and Educational Planning 49, 3 (2005): 374. 
${ }^{7}$ Jan H.F. Meyer and Ray Land, "Stop the Conveyor Belt, I Want to Get Off," Times Higher Education Supplement, no. 1807, August 17, 2007,

http://www.timeshighereducation.co.uk/story.asp?sectioncode $=26 \&$ storycode $=90288$ (accessed 8 April 2011).

${ }^{8}$ Ursula Lucas and Rosina Mladenovic, “Developing New 'World Views': Threshold Concepts in Introductory Accounting," in Overcoming Barriers to Student Understanding,ed. Meyer and Land,157.

${ }^{9}$ Meyer and Land, Threshold Concepts and Troublesome Knowledge: Linkages, 10.

${ }^{10}$ Glynis Cousin, "Threshold Concepts: Old Wine in New Bottles or New Forms of

Transactional Curriculum Inquiry?" in Threshold Concepts Within the Disciplines, ed. Ray Land, Jan H.F. Meyer, and Jan Smith, (Rotterdam: Sense Publishers, 2008), 140.

${ }^{11}$ Ibid.

${ }^{12}$ Cousin, "Threshold Concepts: Old Wine"; Anna Eckerdal, Robert McCartney, Jan Erik

Mostrom, Mark Ratcliffe, Kate Sanders, and Carol Zander, "Putting Threshold Concepts into

Context in Computer Science Education," in Proceedings of the 11th Annual SIGCSE

Conference on Innovation and Technology in Computer Science Education, eds. Michael

Goldweber and Paola Salomoni (New York: Association for Computing Machinery, 2006);

Anastasia Efklides, "Metacognition, Affect, and Conceptual Difficulty," in Overcoming Barriers to Student Understanding, ed. Meyer and Land, 48-69 ; Ursula Lucas and Rosina Mladenovic, "The Potential of Threshold Concepts: An Emerging Framework for Educational Research and Practice," London Review of Education 5, 3 (2007). 
${ }^{13}$ Denyse B. Rodrigues and DeNel Rehberg Sedo, "Experiencing Information Literacy in Second Life," Partnership: The Canadian Journal of Library and Information Practice and Research 3, 1 (2008), http://journal.lib.uoguelph.ca/index.php/perj/article/view/426/860 (accessed 8 April 2011).

${ }^{14}$ Phil Yorke-Barber, Loretta Atkinson, Gisela Possin, and Leith Woodall, "Light Bûlb Moments: Identifying Information Research Threshold Concepts for Fourth Year Engineering Students," in To Industry and Beyond: Proceedings of the 2008 AaeE Ninéteenth Annual Conference for the Australasian Association for Engineering Education, ed. Llewellyn Mann, Adam Thompson, and Prue Howard (Yeppoon, Central Queenstand, 7th - 10th December 2008). http://espace.library.uq.edu.au/eserv/UQ:159735/aaee08_submission_T1C2.pdf (accessed 8 April 2011).

${ }^{15}$ Margaret Blackmore, "Student Engagementwith Information: Applying a Threshold Concept Approach to Information Literacy Development," (paper presented at the 3rd Biennial Threshold Concepts Symposium: Exploring Transformative Dimensions of Threshold Concepts; Sydney, Australia, 1-2 July 2010).

${ }^{16}$ Rodrigues and Sedo, "Experiencing Information Literacy," 3.

${ }^{17}$ Yorke-Barber êt al., "Light Bulb Moments," 5.

${ }^{18}$ Blackmore, "Student Engagement with Information," 3.

${ }^{19}$ Meyer and Land, Threshold Concepts and Troublesome Knowledge: Linkages, 3.

${ }^{20}$ Blackmore, "Student Engagement with Information," 9-10.

${ }^{21}$ Rodrigues and Sedo, "Experiencing Information Literacy,” 3; Yorke-Barber et al., "Light Bulb Moments," 5. 
${ }^{22}$ Blackmore, "Student Engagement with Information," 5, 7-8.

${ }^{23}$ Naomi Irvine and Patrick Carmichael, "Threshold Concepts: A Point of Focus for Practitioner Research," Active Learning in Higher Education 10, 2 (2009): 112.

${ }^{24}$ Association of College and Research Libraries, Information Literacy Competency Standards for Higher Education, http://www.ala.org/ala/mgrps/divs/acrl/standards/informationliteracycompetenov.cfm (accessed 8 April 2011).

${ }^{25}$ Hannelore B. Rader, "Information Literacy 1973-2002: A Selected Literature Review," Library Trends 51, 2 (2002): 242.

${ }^{26}$ Kerr, "Conceptions and Practice of Information Literacy," 19.

${ }^{27}$ See William Badke, ”A Rationale for Information Literacy as a Credit-bearing Discipline," Journal of Information Literacye2, no. 1 (2008), http://jil.lboro.ac.uk/ojs/index.php/JIL/article/view/RA-V2-I1-2008-1 (accessed 8 April 2011); Sheila Webber and Bill Johnston, "Conceptions of Information Literacy: New Perspectives and Implications," Journal of Information Science 26, 6 (2000): 381-397.

${ }^{28}$ Grant P. Wiggins and Jay McTighe, Understanding by Design (Upper Saddle River, N.J.: Pearson Education, Inc, 2005), 60-62.

${ }^{29}$ Association of College and Research Libraries, Information Literacy Competency Standards. ${ }^{30}$ Edward K. Owusu-Ansah, "Information Literacy and the Academic Library: A Critical Look at a Concept and the Controversies Surrounding It," The Journal of Academic Librarianship 29, 4 (2003): 226.

${ }^{31}$ Wiggins and McTighe, Understanding by Design, 62. 
${ }^{32}$ California State University, "Transforming Course Design in the CSU,"

http://teachingcommons.cdl.edu/tcd/index.html (accessed 8 April 2011).

${ }^{33}$ Korey Brunetti and Lori Townsend, "Extreme (Class) Makeover: Engaging Information

Literacy Students with Web 2.0," in Proceedings of World Conference on E-Learning in

Corporate, Government, Healthcare, and Higher Education, (Quebec City, 15 October 2007),

ed. Theo Bastiaens and Saul Carliner (Chesapeake, VA: AACE, 2007).

${ }^{34}$ David Perkins, "Constructivism and Troublesome Knowledge," in Overcoming Barriers to Student Understanding, ed. Meyer and Land, 40.

${ }^{35}$ Lori Townsend, Korey Brunetti, and Amy R. Hofer, "Save a Horse, Ride a New Train of Thought: Using Threshold Concepts to Teach Information Literacy," in Blazing Trails: On the Path to Information Literacy Proceedings of the Thirty-sixth National LOEX Library Instruction Conference, (Albuquerque, New Mexico, Aprit 1 - May 1, 2009), ed. Brad Seitz. (Ypsilanti, Mich.: University Library, Eastern Michigan University, LOEX Press, forthcoming).

${ }^{36}$ Meyer and Land, Threshold Concepts and Troublesome Knowledge (2), 373.

${ }^{37}$ Perkins, "Constructivism and Troublesome Knowledge."

${ }^{38}$ ACRL, Information Literacy Competency Standards.

${ }^{39}$ Badke, “A Rational for Information Literacy,” 12.

${ }^{40}$ For example, see Brian Martin, Information Liberation: Challenging the Corruptions of Information Power. (London: Freedom Press, 1998).

${ }^{41}$ Reference and User Services Association, History Section, "Using Primary Sources on the Web," Reference and User Services Association, 
http://www.ala.org/ala/mgrps/divs/rusa/sections/history/resources/pubs/usingprimarysources/ind ex.cfm (accessed 8 April 2011).

${ }^{42}$ Glynis Cousin, ”An Introduction to Threshold Concepts," Planet, no. 17, (2006): 4, http://gees.ac.uk/planet/p17/gc.pdf (accessed 8 April 2011).

${ }^{43}$ Margaret Kiley and Gina Wisker, "Threshold Concepts in Research Education and Evidence of Threshold Crossing," Higher Education Research and Development 28, 4 (2009): 431, doi:10.1080/07294360903067930.

${ }^{44}$ Blackmore, "Student Engagement with Information."

${ }^{45}$ Chris Cope and Lorraine Staehr, "Improving Student Learning About a Threshold Concept in the IS Discipline," Informing Science: the International dournal of an Emerging Transdiscipline 11, (2008), http://www.inform.nu/Articles/Vol11/ISJv11p349-364Cope217.pdf (accessed 8 April 2011).

${ }^{46}$ Peter Davies, "Threshold Concepts: How Can We Recognise Them?," 7-8. 